\title{
The phytotoxicity of disinfectants and their effect at different temperatures
}

\author{
Hanna Avikainen, HilkKa Koponen, Beata Meinander and \\ RISTO TAHVONEN
}

\begin{abstract}
Avikainen, H., Koponen, H., Meinander, B. \& Tahvonen, R. 1993. The phytotoxicity of disinfectants and their effect at different temperatures. Agric. Sci. Finl. 2: 161-168. (Agric. Res. Centre of Finland, Inst. PI. Prot., FIN-31600, Jokioinen, Finland and Dept. Plant Biology, P.O.Box 28, FIN-00014 Univ. Helsinki, Finland.)
\end{abstract}

\begin{abstract}
When disinfecting plastic growth containers, only sodium hypochloride $(\mathrm{NaClO})$ caused damage both to cucumber and lettuce seedlings grown on peat if the containers had not been washed with water after disinfection. Also the seedlings grown on rockwool cubes were susceptible to Menno-Ter-forte when the growth containers were not properly rinsed after disinfection. All tested disinfectants caused damage to cucumber, lettuce and cauliflower seedlings when mixed in the peat substrate.

The efficiency of disinfectants was higher at $+20^{\circ} \mathrm{C}$ than at $+5^{\circ} \mathrm{C}$, especially against Fusarium culmorum, F. oxysporum and Rhizoctonia solani. A decrease in temperature affected least the efficacy of $\mathrm{NaOCl}$ and Menno-Ter-forte and most that of Virkon S.
\end{abstract}

Key words: cauliflower, cucumber, disinfection, lettuce

\section{Introduction}

With increasing and rationalisation of greenhouse cultivation better hygiene in greenhouses is required than previously. With expanding horticultural markets the risk of spread of plant pathogens has increased. Previously, disinfection of greenhouses consisted mainly of disinfection of the substrate (LINNASALMI 1955). Disinfection of soil has, however, become unnecessary as the growth substrate is changed after each growing period and it is used in plastic containers. Disinfection of structures and equipment still is important, because many plant pathogens may survive long in plant debris and in soil particles.

There are several disinfectants on the market. Many of them have been developed for use in domestic animal farms and food production, not actu- ally for disinfection of greenhouses. The disinfectants for use in greenhouses must be effective against plant pathogens and harmless to the plants. There is little information about the phytotoxicity of disinfectants. Formaldehyde fumes at high temperatures and causes damage to flowers and plants (STRAETMANS 1984). This has been observed in greenhouses when the temperature has been increased after disinfection. Formaline residues in the substrate have caused damage to cabbage seedlings (LINNASALMI 1952, 1955).

Thorough cleaning of greenhouses and storages is recommended in autumn, at the end of the growing season when the greenhouse is emptied, and the temperature is decreased. The best disinfection result is, however, obtained in conditions favourable to the growth of microbes $\left(+20-30^{\circ} \mathrm{C}\right.$, humidity $70-90 \%$ ) (ENGVALL 1988). The optimum temper- 
ature for a number of disinfectants is approx. $+20^{\circ} \mathrm{C}$. Formaline, for instance, is inactivated at below $+15^{\circ} \mathrm{C}$ (ÅKESSON 1990).

The aim of the present study was to determine the phytotoxicity of disinfectants as well as their efficacy at different temperatures. The study was carried out in 1988-1990 at the Institute of Plant Protection of the Agricultural Research Centre.

\section{Material and methods}

\section{Disinfectants}

The phytotoxicity of seven disinfectants (Table 1) was studied on seedlings of cucumber, lettuce and cauliflower and the effect of disinfectants on nine fungi at different temperatures. Formaline was included only in the temperature trials. The concentrations recommended by the manufacturers were used. The dilutions were made in distilled water for the laboratory trials and in tap water for the greenhouse trials.

Table 1. The disinfectants, their active ingredients and concentrations recommended by the manufacturers.

\begin{tabular}{llc}
\hline Disinfectant & Active ingredient, \% & $\begin{array}{c}\text { Recom- } \\
\text { mended } \\
\text { concentra- } \\
\text { tion, } \%\end{array}$ \\
\hline $\begin{array}{l}\text { Formaline } \\
\text { Iobac P }\end{array}$ & $\begin{array}{l}\text { Formaldehyde, } 37 \\
\text { Ipasept }\end{array}$ & 5.0 \\
Kodine, 1.8 & 3.0 \\
Menno-Ter-forte & $\begin{array}{l}\text { Quaternary ammonium } \\
\text { Qumpounds, 2.8 }\end{array}$ & 2.0 \\
Quanisept & $\begin{array}{l}\text { compounds, 32.8 } \\
\text { Quaternary ammonium } \\
\text { compounds, 2.5 }\end{array}$ & 1.0 \\
Sodium hypochlorite & Active chlorine, 10 \\
(NaOCl) & Potassium peroxysul- & 1.0 \\
Virkon S & phate, 60 & 2.0 \\
& & 1.0 \\
\hline
\end{tabular}

\section{Phytotoxicity of disinfectants}

In the phytotoxity trials, cucumber variety 'Daleva', lettuce varieties 'Cortina' and 'Grand Rapids' and cauliflower variety 'Tanskalainen suuri' were used as test plants. The growth temperature was $+18-20^{\circ} \mathrm{C}$ for lettuce and cauliflower and $+22-25^{\circ} \mathrm{C}$ for cucumber. Additional light of 6000 lux was given to the seedlings. The growth peat was fertilized with $150 \mathrm{~g}$ peat compound fertilizer and $800 \mathrm{~g}$ Dolomite lime/100 I peat.

\section{Disinfection of plastic pots}

The phytotoxicity of disinfection of plastic growth containers (Vefi) and plastic pots (1 dl) was tested on lettuce and cucumber. Peat was used as the growing medium. The containers were soaked in a disinfection suspension for four hours and the pots for three hours. Half of the $\mathrm{NaOCl}$ treated pots were washed under running water. The pots immersed in other disinfectants were not washed. On the day after disinfection lettuce seeds were sown in the containers and cucumber seeds in the pots. The lettuce trial consisted of three replicates with 32 seeds, and the cucumber trial of five replicates with two seeds per replicate. The condition of seedlings was checked three weeks after sowing. The plants were evaluated visually on a rating scale of 0-3:0= no damage, 1 = slight damage, growth suppressed, 2 = clear damage, growth clearly suppressed and 3 $=$ severe damage, plant and roots dead. The fresh weight of the seedlings was also recorded. Analysis of variance was used in the statistical analysis of the results, and significances were tested with Dunnet's test.

The effect of Menno-Ter-forte on plants grown on rockwool was studied in the following experiment. Plastic boxes $(50 \times 25 \times 9.5 \mathrm{~cm})$ were soaked for $60 \mathrm{~min}$ in $1 \%$ Menno-Ter-forte solution. Half of the boxes were washed under running water. The boxes were allowed to dry for four hours. Thereafter rockwool and peat cubes $(4 \times 4 \times 4 \mathrm{~cm})$ were placed into the disinfected boxes. The test plants were cucumber and lettuce. Before sowing the rockwool cubes were soaked wet in $0.05 \%$ fertilizer solution containing hydrofertilizer and lime salpeter (2:1). The cucumber trial consisted of four replicates with 15 plants and the lettuce trial of three replicates with 25 plants. The treatments 
were: no disinfection, disinfection with no washing and disinfection with washing.

The cucumber trial lasted 10 days and the lettuce trial three weeks after sowing. At the end of the trial the height and fresh weight of seedlings were measured and the damage caused to the plants was evaluated on a rating scale of $0-2$ : $0=$ no damage, 1=slight damage, 2 =leaves dark green, growth stopped or dead seedling. The growth index was determined with the formula:

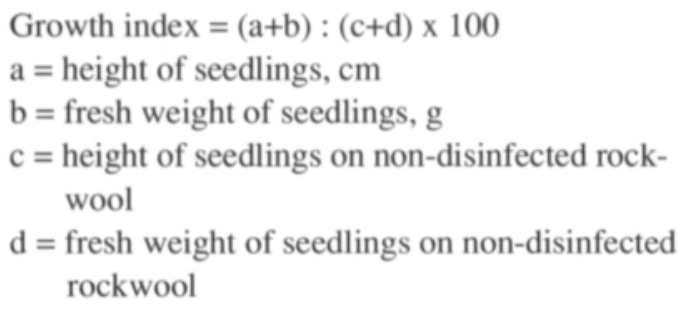

In the rockwool trials the results were analysed with the split-plot analysis of variance and significances were tested with Tukey's test.

\section{Phytotoxicity of disinfectants mixed in peat}

The phytotoxicity of the disinfectants in peat was studied on lettuce, cucumber and cauliflower. The disinfectant was mixed $0,0.01,0.1,0.5,1.0,2.0$ and $5.0 \mathrm{ml}$ or $\mathrm{g}$ per 11 peat. In addition, the substrate of cauliflower was treated by $2.5 \mathrm{ml}$ or $\mathrm{g}$. The disinfectant was diluted in $125 \mathrm{ml}$ of water which was mixed in 11 of peat. The peat was divided into pots where the seeds were sown or the seedlings planted. The seeds were covered with untreated peat.

One-week-old cucumber seedlings were planted into 0.51 pots. The trial was made with five replicates and two seedlings per replicate. Three weeks after planting the height and fresh weight of seedlings were recorded and the condition of shoots and roots was evaluated visually on a rating scale of 0-3: $0=$ no damage, $1=$ slight damage, growth suppressed, $2=$ evident damage, growth inhibited, $3=$ growth stopped, dead plant.

The lettuce trial was made with three replicates and 32 seedlings per replicate. Three and four weeks after sowing the degree of infection was determined randomly on 15 plants on a rating scale of $0-3$ as in the cucumber trial. The fresh weight of the seedlings was also recorded.

In the cauliflower trial there were four replicates and 36 seeds per replicate. The height of the seedlings was recorded two weeks after sowing. At the end of the trial (three weeks after sowing) the fresh weight of plants was recorded and the damage was evaluated on a rating scale of $0-3$ as in the cucumber trial.

Analysis of variance was used in the statistical analysis of the results. Significances were tested with Dunnet's test. A phytotoxicity limit was defined as the lowest concentration of disinfectant mixed in peat causing clear damage to plants or reduction in the height, or the fresh weight was determined for each disinfectant.

\section{The effect of temperature on the disinfection efficiency}

Nine fungi were included in the temperature study (Table 2). The names of the fungi are mainly according to DoMSCH et al. (1980). The fungal isolates were obtained from the collections of the Institute of Plant Protection of the Agricultural Re-

Table 2. The fungi and the growth media used in temperature tests.

\begin{tabular}{|c|c|}
\hline Fungus & Growth medium \\
\hline Botrytis cinerea & $\begin{array}{l}\text { Corn meal agar (Difco) }+100 \mathrm{ppm} \\
\text { streptomycin sulphate }\end{array}$ \\
\hline Didymella bryoniae & $\begin{array}{l}\text { Corn meal agar (Difco) }+100 \mathrm{ppm} \\
\text { streptomycin sulphate }\end{array}$ \\
\hline $\begin{array}{l}\text { Fusarium culmorum, } \\
\text { F. oxysporum }\end{array}$ & Nash and Snyder PCNB medium \\
\hline $\begin{array}{l}\text { Mycocentrospora } \\
\text { acerina }\end{array}$ & $\begin{array}{l}\text { Corn meal agar (Difco) }+100 \mathrm{ppm} \\
\text { streptomycin sulphate }\end{array}$ \\
\hline Phoma foveata & $\begin{array}{l}\text { Malt extract agar (Difco), } \\
\text { Corn meal agar (Difco) }+100 \text { ppm } \\
\text { streptomycin sulphate }\end{array}$ \\
\hline Pythium sp. & Martin's medium \\
\hline Rhizoctonia solani & $\begin{array}{l}\text { Rhizoctonia agar (Ko and HorA } \\
\text { 1971) }\end{array}$ \\
\hline Verticillium dahliae & $\begin{array}{l}\text { Corn meal agar (Difco) }+100 \mathrm{ppm} \\
\text { streptomycin sulphate }\end{array}$ \\
\hline
\end{tabular}


search Centre. In the trial the fungi were isolated and cultivated on different growth media depending on the fungus species (Table 2). The formulas for media are presented in BoOTH (1971).

The choice of temperatures, $+5^{\circ} \mathrm{C},+10^{\circ}$ and $+20^{\circ} \mathrm{C}$, was based on previous experience. Before the test all solutions, pots and equipment were kept for 12 hours in these temperatures. Plastic pots were scratched with sandpaper and contaminated with fungus-peat suspension. The inoculate used was obtained by mixing one plate of fungus (Fusarium culmorum, $F$. oxysporum, Mycocentrospora acerina, Phoma foveata, Pythium sp., Rhizoctonia solani and Verticillium dahliae) and $100 \mathrm{ml}$ sterile water in one litre of peat, or by mixing five crushed pieces ( $4 \mathrm{~cm}$ long) of infected (Botrytis cinerea and Didymella bryoniae) plant and $100 \mathrm{ml}$ sterile water in one litre of peat.

Contaminated plastic pots were dried for 1-2 days. Pieces $(4 \times 6 \mathrm{~cm})$ of the pots were immersed in disinfectant for $60 \mathrm{~min}$ and rinsed with water. Pieces $(\varnothing 0,5 \mathrm{~cm})$ of plastic pots were placed on different agar plates (4 pieces plate) depending on the test fungus (Table 2) to determine the susceptibility of the fungi to the disinfectant. The plates were kept at $+20^{\circ} \mathrm{C}$. The trial consisted of three replicates with three plates. The experiment was repeated twice for Iobac P, Menno-Ter-forte, $\mathrm{NaOCl}$ and Virkon S. Water was used in the control treatment. The results of temperature trials were calculated as efficiency percentages, i.e. as the proportion of healthy pieces of all pieces.

\section{Results}

\section{Phytotoxicity of disinfectants}

Of the eight disinfectants tested, only $\mathrm{NaOCl}$ caused visible damage both to lettuce and cucumber seedlings when the plastic growth containers and pots had been disinfected and seedlings were grown on peat. Damage was observed on the leaf margins, the seedlings were clearly shorter and their fresh weight lower compared to the controls and other treatments (Figs. 1-2). $\mathrm{NaOCl}$ treatment caused damage also to the cucumber roots. Rinsing

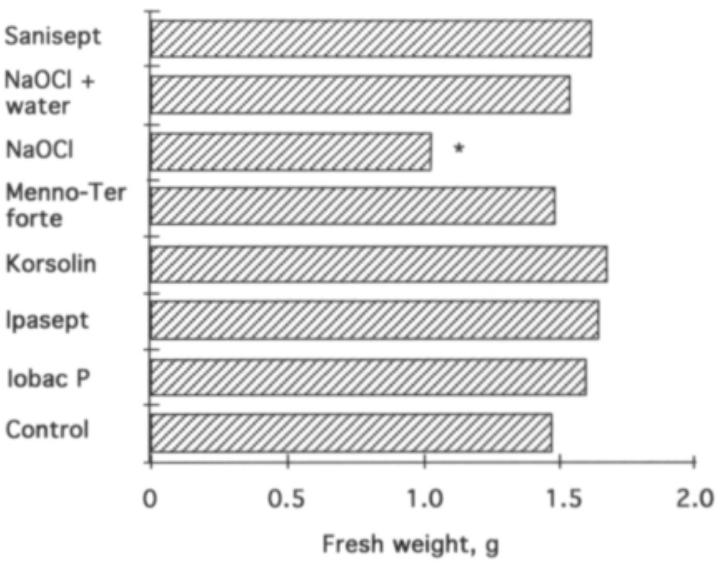

Fig. 1. The effect of disinfection of plastic growth containers on the fresh weight of lettuce seedlings grown on peat substrate. $\mathrm{F}=4.41, \mathrm{p}<0.01 .{ }^{*}=$ significantly smaller than control, $\mathrm{p}<0.05$.

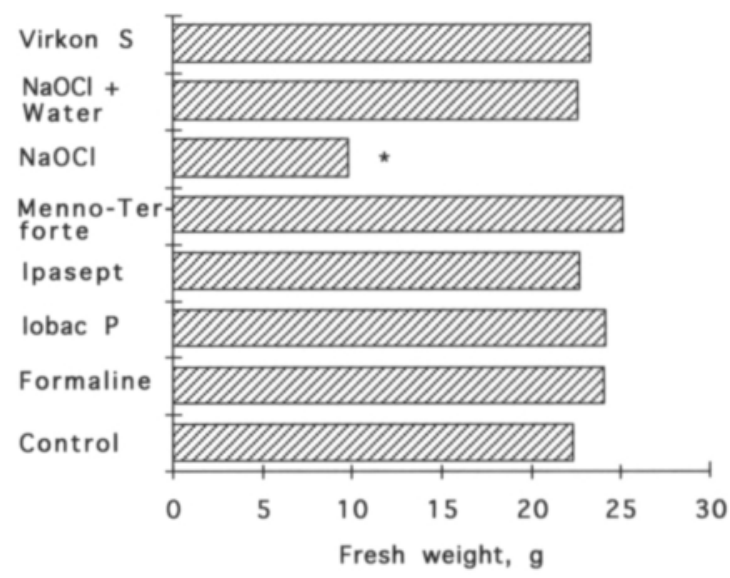

Fig. 2. The effect of disinfection of plastic growth pots on the fresh weight of cucumber seedlings grown on peat substrate. $\mathrm{F}=3.16, \mathrm{p}<0.01 .{ }^{*}=$ significantly smaller than the control, $\mathrm{p}<0.05$.

with water eliminated the phytotoxicity of $\mathrm{NaOCl}$.

Disinfection of the plastic boxes with MennoTer-forte caused clear symptoms in cucumber seedlings grown on rockwool. The seedlings remained short and they were dark green compared to the control. Rinsing the boxes with water did not remove the disinfectant totally; some damage was still observed in the seedlings. Disinfection did not damage seedlings grown in peat; their vigour even increased (Table 3). 
Table 3. Disinfection of plastic boxes with Menno-Ter-forte and the effect of treatment on the growth of cucumber and lettuce seedlings grown on rockwool and peat.

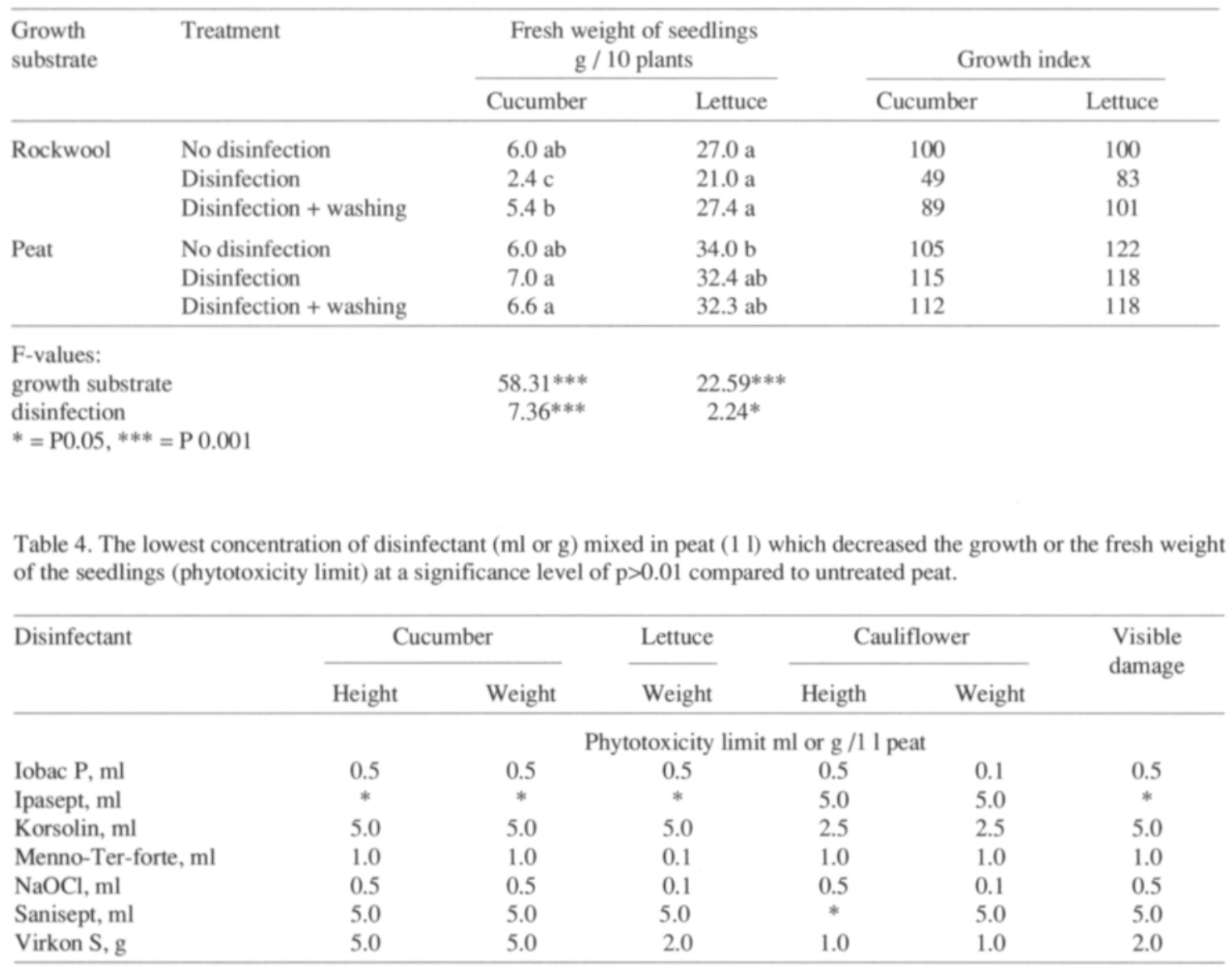

* no phytotoxicity

Disinfection of plastic boxes with Menno-Terforte decreased also the fresh weight and the height of lettuce grown also on rockwool. Rinsing with water eliminated the phytotoxicity completely. Lettuces grown on peat were not damaged by disinfection at all (Table 3).

$\mathrm{NaOCl}$ mixed in peat caused chlorocity and greyish brown spots on the leaves of cucumber, lettuce and cauliflower seedlings, growth stopped and the plants died. The phytotoxicity limit, $0.1 \mathrm{ml}$, caused slight damage to lettuce and cauliflower. Half a millilitre of $\mathrm{NaOCl}$ damaged clearly cucumber and cauliflower; the growth of lettuce stopped totally. More than $1 \mathrm{ml}$ caused damage to cucumber roots. Five millilitres killed all test plants (Table 4).

Iobac P mixed in peat caused dark brown spots on the leaves and stunted growth in all test plants. The lowest amount of Iobac P that caused slight damage to lettuce and cucumber and clear damage to cauliflower was $0.5 \mathrm{ml}$. More than $2.5 \mathrm{ml}$ inhibited the development of the plants. The phytotoxicity limit of Iobac P was $0.5 \mathrm{ml} / 11$ peat (Table 4).

In the Menno-Ter-forte treatment of peat, the leaves of all test plats were dark green and the plants stunted compared to the controls. One week after the treatment all amounts of the disinfectant caused slight damage to the cucumber seedlings, but the damage disappeared later. The phytotoxic- 
Table 5. The effect of temperature $\left(+5,+10 \mathrm{ja}+20^{\circ} \mathrm{C}\right)$ on the disinfection efficiency against fungi on plastic surfaces. Disinfection time $60 \mathrm{~min}$.

\begin{tabular}{lcccccccc}
\hline Fungus & Water & Formaline & Iobac P & $\begin{array}{c}\text { Disinfectant } \\
\text { Ipasept } \\
\text { Korsolin } \\
\end{array}$ & \multicolumn{7}{c}{$\begin{array}{c}\text { Menno- } \\
\text { Ter-forte }\end{array}$} & NaOCl & Virkon S \\
\hline Botrytis cinerea & $20 / 28$ & $5 / 100$ & $5 / 100$ & $5 / 100$ & $10 / 100$ & $5 / 100$ & $5 / 100$ & $10 / 100$ \\
Didymella bryoniae & $20 / 11$ & $5 / 100$ & $5 / 100$ & $5 / 100$ & $5 / 100$ & $5 / 100$ & $5 / 100$ & $5 / 100$ \\
Fusarium culmorum & $20 / 18$ & $20 / 100$ & $5 / 100$ & $20 / 58$ & $20 / 100$ & $10 / 100$ & $5 / 100$ & $20 / 89$ \\
Fusarium oxysporum & $20 / 4$ & $20 / 75$ & $20 / 100$ & $20 / 92$ & $20 / 83$ & $10 / 99$ & $5 / 100$ & $20 / 95$ \\
Mycocentrospora acerina & $20 / 31$ & $20 / 100$ & $5 / 100$ & - & - & $5 / 100$ & $5 / 100$ & $5 / 100$ \\
Phoma foveata & $20 / 27$ & $20 / 67$ & $5 / 100$ & $5 / 100$ & $5 / 100$ & $5 / 100$ & $5 / 100$ & $20 / 100$ \\
Pythium sp. & $20 / 56$ & $5 / 100$ & $5 / 100$ & $10 / 92$ & $20 / 100$ & $20 / 100$ & $5 / 100$ & $20 / 100$ \\
Rhizoctonia solani & $20 / 17$ & $20 / 100$ & $10 / 100$ & $10 / 100$ & $20 / 58$ & $20 / 100$ & $5 / 100$ & $20 / 100$ \\
Verticillium dahliae & $20 / 46$ & $5 / 100$ & $10 / 100$ & - & - & $20 / 99$ & $5 / 100$ & $20 / 96$ \\
\hline
\end{tabular}

ity limit of Menno-Ter-forte was $1 \mathrm{ml} / 1 \mathrm{l}$ peat, which caused damage to the cucumber roots, lettuce and cauliflower (Table 4).

One gram of Virkon S mixed in peat caused slight damage to cauliflower. Two grams clearly disturbed the growth of cauliflower, cucumber and lettuce. Five grams of Virkon $\mathrm{S}$ inhibited the growth of all test plants. The phytotoxicity limit was $2 \mathrm{~g} / 11$ peat (Table 4).

The phytotoxicity limit of Korsolin was $2.5 \mathrm{ml} / 1$ 1 peat. This quantity caused slight growth disturbances to cauliflower, and $5 \mathrm{ml}$ caused clear symptoms in lettuce and cucumber. The phytotoxicity limit of Sanisept was $5 \mathrm{ml} / 11$ peat. Ipasept was the least phytotoxic of the disinfectants studied. In cucumber and lettuce it caused no damage and $5 \mathrm{ml}$ caused slight damage to cauliflower (Table 4).

\section{The effect of temperature on the efficiency of disinfectants}

At $+5^{\circ} \mathrm{C}, \mathrm{NaOCl}$ maintained best its efficiency against all fungi. Also Iobac $\mathrm{P}$ and Menno-Ter-forte were rather effective in this temperature. Formaline was effective at $+5{ }^{\circ} \mathrm{C}$ against Botrytis cinerea, Didymella bryoniae, Pythium sp. and Verticillium dahliae. The efficiency of Virkon $\mathrm{S}$ increased clearly at $+20^{\circ} \mathrm{C}$. Korsolin and Ipasept were weak at all temperatures. In the control of Fusarium cul- morum, $F$. oxysporum and $R$. solani the disinfectants were most effective at $+20^{\circ} \mathrm{C}$. For eradication of B. cinerea, D. bryoniae and Phoma foveata, temperatures of $+5{ }^{\circ} \mathrm{C}$ and $+10^{\circ} \mathrm{C}$ were sufficient for Iobac P, Menno-Ter-forte or $\mathrm{NaOCl}$ (Table 5).

\section{Discussion}

$\mathrm{NaOCl}$ and Iobac $\mathrm{P}$ mixed in peat were the most phytotoxic disinfectants. Clear damage was observed in lettuce, cucumber and cauliflower when $0.5 \mathrm{ml}$ of either preparation was mixed in peat. In addition, $\mathrm{NaOCl}$ was the only preparation which caused damage to cucumber and lettuce seedlings grown on peat if the growth containers had not been rinsed with water after disinfection. In previous studies, $\mathrm{NaOCl}$ has not been reported to cause damage to lettuce and cress (BÖHMER 1983, 1985).

When mixed in peat, Menno-Ter-forte $1 \mathrm{ml} / 1 \mathrm{l}$ peat caused damage to the test plants. Clear damage was observed in cucumber and lettuce seedlings grown on rockwool cubes if the growth container had not been thoroughly washed with water after disinfection with Menno-Ter-forte. According to ÅKESSON (1990), too, all surfaces getting in contact with the plants should be washed after Menno-Terforte treatment. BÖHMER (1983) reported MennoTer to cause spots in lettuce seedlings and to decrease the formation of primary roots in cress. Ac- 
cording to JoHANSSON (1985), Menno-Ter Special and Korsolin caused slight damage to pelargonias and begonias.

There is evidence of the phytotoxicity of formaline and disinfectants containing formaldehyde on Saintpaulia ionatha leaf cuttings (WOHANKA and DOLL 1985), pelargonias and begonias (JOHANSSON 1985), as well as on cress, lettuce (BÖHMER 1983, 1985) and cabbage seedlings (LINNASALMI 1952). Formaline was not included in the present phytotoxicity studies, but there is evidence of the phytotoxicity of formaline on rape seedlings in other trials (MEINANDER 1991).

In the present study, small seedlings were used in the phytotoxicity tests. The seedlings could revive from the damage caused by some disinfectants (e.g. Menno-Ter-forte) in a couple of weeks. The trials should, however, have been continued longer to confirm the revival. The effect of temperature, light and humidity on the phytotoxicity was not studied.

When using disinfectants, careful washing after disinfection is essential, especially when using synthetic media and water cultures.

For most disinfectants, the optimum disinfection temperature is $+15-20^{\circ} \mathrm{C}$ (SUNDHEIM 1991). Low temperatures require longer exposure times and higher concentrations than higher temperatures (BAANDRUP 1984). For formaldehyde (formaline), the optimum temperature is approx. $+20^{\circ} \mathrm{C}$. Formaldehyde is inactivated at below $+15^{\circ} \mathrm{C}$ ( $\AA$ KESSON 1990, BÅNG 1987a, b, SUNDHEIM 1991). BÅNG (1987b) observed formaline to be active against
Phoma foveata and Fusarium solani even in the gaseous form at a temperature as low as $+10^{\circ} \mathrm{C}$. In the present trials, formaline was effective against Botrytis cinerea, Didymella bryoniae, Pythium sp. and Verticillium dahliae after $60 \mathrm{~min}$ also at $+5^{\circ} \mathrm{C}$. Against other fungi formaline affected best at $+20^{\circ} \mathrm{C}$

$\mathrm{NaOCl}$ was the most effective of the tested disinfectants at $+5^{\circ} \mathrm{C}$, but also Iobac $\mathrm{P}$ and Menno-Terforte were effective. According to ÅKESSON (1990), Menno-Ter-forte was the most effective at over $+19^{\circ} \mathrm{C}$, but the preparation performed well also at $+5^{\circ} \mathrm{C}$. Glutaraldehyde containing preparations (Korsolin, Glu-cid) can be used at temperatures as low as $+5^{\circ} \mathrm{C}$ (ÅKESSON 1990, ENGVALL 1988). In the present study, Korsolin (1\%) was most effective at $+20^{\circ} \mathrm{C}$. The recommended concentrations for Korsolin are $1 \%$ at over $+18^{\circ} \mathrm{C}, 2 \%$ at $+10-18^{\circ} \mathrm{C}$ and $3 \%$ at below $+10^{\circ} \mathrm{C}$ (ÅKESSON 1990, BAANDRUP 1984).

The efficacy of Virkon S increased at higher temperatures. The weak efficiency of the preparation at low temperatures is partly due to the powder being poorly soluble in cold water. Therefore Virkon S should be mixed in lukewarm water. Disinfection should be done at temperatures higher than $+15^{\circ} \mathrm{C}$. According to the present trials, below $+10^{\circ} \mathrm{C}$ it is possible to use against Botrytis cinerea, Didymella bryoniae, Mycocentrospora acerina and Phoma foveata $\mathrm{NaOCl}$, Menno-Ter-forte and Iobac $\mathrm{P}$ compounds.

\section{References}

ÅKESson, I. 1990. Sanering och hygien i växthus. Sveriges Lantbruksuniversitet. Faktablad om växtskydd. Trädgård $4 \mathrm{~T}$.

BAANDRUP, M. 1984. Desinfektion af undervandingsmåtter. Gartner Tidende 10: 285-287.

BÁNG, U. 1987a. Försök med desinfektionsmedel. Spor potatisodl. 5 (2): 32-34.

- 1987b. Redovisning av försök med desinfektioin genom dimning i konstantrum vid Röbäcksdalen i september 1986. Mimeogr.

Bӧнек, В. 1983. Untersuchungen zum Einsatz von Desinfektionsmitteln im Zierpflanzenbau. Gesunde Pfl. 35: 189-197.

- 1985. Nicht alle Mittel wirken unter Schmutzbelastung.
Gärtnerbör. und Gartenw. 85: 836-838.

Bоотн, C. 1971. Methods in microbiology. Academic Press. London. Vol. 4. 795 p.

Domsch, K. H., Gams, W. \& Anderson, T.-H. 1980. Compendium of soil fungi. Academic Press. London. Vol. 1.859 p.

Engvall, A., Suölander, A. \& Olssson, S.-O. 1988. Desinfektionsmedel vid djurhållning. Svensk husdjursskötsel. Meddelande 154. Eskilstuna. 21 p.

Johansson, A.-K. 1985. Löpande desinfektion i växthus av Xanthomonas pelargonii och $X$. begoniae. Disinfection in greenhouses of Xanthomonas pelargonii and X. begoniae. Institutionen för växt- och skogsskydd. (Sveriges Lantbr. Univ). Examensarbeten 1985 (5). Uppsala. 67 p. 
Ko, W.-H. and HorA, F. K., 1971. A selective medium for quantitative determination of Rhizoctonia solani in soil. Phytopathology 61: 707-710.

LinNASALMi, A. 1952. Damping-off on herbaceous vegetables and ornamental plants grown under glass in Finland. Ann. Bot. Soc. 'Vanamo' 26, (1): 1-120.

- 1955. Maan desinfiointi. Puutarhaviljelijäin liiton julkaisuja N:o 111. Helsinki. 46 p.

Meinander, B. 1991. Desinfektionsmedels fytotoxiska verkan vid användning $\mathrm{i}$ växthus. Institutionen för trädgårdsvetenskap. University of Helsinki. Helsinki. 82 p.

Straetmans, U. 1984. Abbaureaktionen von Desinfektionsmitteln. Champignon 24 (272): 17-26.

SundHeIm. L. 1991. Reingering og desinfeksjon mot sjukdomar i veksthus. Plantevern i veksthus. Etterutdanninngskurs arrangert av statens fagtjeneste for land- bruket. Mimeogr. 5 p.

Wohanka, W. \& Doll, W. 1985. Was leisten Desinfektionsmittel in der Praxis? Deut. Gartenb. 31: 1482-1483.

Manuscript received July 1992

Hanna Avikainen

Risto Tahvonen

Agricultural Research Centre of Finland

Institute of Plant Protection

FIN-31600 Jokioinen, Finland

Hilkka Koponen

Beata Meinander

Department of Plant Biology

P.O.Box 28

FIN-00014 University of Helsinki, Finland

\title{
SELOSTUS
}

\section{Desinfiointiaineiden fytotoksisuus ja tehokkuus eri lämpötiloissa}

\author{
Hanna Avikainen, HilkKa Koponen, Beata Meinander ja Risto \\ TAHVONEN
}

Maatalouden tutkimuskeskus ja Helsingin yliopisto

\begin{abstract}
Maatalouden tutkimuskeskuksen kasvinsuojelulaitoksella selvitettiin seitsemän desinfiointiaineen fytotoksisuutta kurkun, salaatin ja kukkakaalin taimiin. Tutkittavat valmisteet olivat Iobac P (jodi), Ipasept, Menno-Ter-forte ja Sanisept (kvartaarisia ammoniumyhdisteitä), Korsolin (glutaraldehydi), natriumhypokloridi (aktiivinen kloori) ja Virkon S (kaliumperoksisulfaatti).

Desinfioitaessa muovisia kasvatuskennoja ja ruukkuja natriumhypokloriitti vioitti sekä kurkun että salaatin taimia turveviljelyssä, ellei astioita huuhdeltu vedellä desinfioinnin jälkeen. Muilla valmisteilla ei vioitusta havaittu. Myös kivivillakuutioissa kasvatetut kurkun ja salaatin taimet olivat herkkiä desinfiointiaineille, kun kasvulaatikoita ei huuhdeltu hyvin desinfioinnin jälkeen. Sensijaan turpeessa kasvatetuissa testikasveissa vioituksia ei todettu. Koe osoitti, että desinfioinnin jälkeen huolellinen huuhtelu on erityisen tarpeen, kun käytetään synteettisiä alustoja ja vesiviljelyä.

Natriumhypokloriitti, Iobac P, Menno-Ter-forte, Korsolin, Virkon S ja Sanisept aiheuttivat turpeeseen sekoitettuina vioi-
\end{abstract}

tuksia kurkun, salaatin ja kukkakaalin taimiin.

Desinfiointiaineiden tehokkuutta eri lämpötiloissa $\left(+5^{\circ} \mathrm{C}\right.$, $+10^{\circ} \mathrm{C}$ ja $+20^{\circ} \mathrm{C}$ ) testattiin laboratoriossa seuraaviin sieniin: Botrytis cinerea, Didymella bryoniae, Fusarium culmorum, $F$. oxysporum, Mycocentrospora acerina, Phoma foveata, Pythium sp., Rhizoctonia solani ja Verticillium dahliae. Kokeissa oli mukana fytotoksisuuskokeissa olleiden valmisteiden lisäksi formaliini (formaldehydi). Valmisteista käytettiin suositeltuja käyttöväkevyyksiä.

Desinfiointiaineiden teho oli parempi $+20^{\circ} \mathrm{C}$ :ssa, kuin $+5{ }^{\circ} \mathrm{C}$ :ssa, erityisesti Fusarium- ja Rhizoctonia-sieniin. Lämpötilan aleneminen vaikutti vähiten $\mathrm{NaOCl}: \mathrm{n}$, Iobac P:n ja Menno-Ter-forten tehoon ja eniten Virkon S:n tehoon.

Tehtyjen kokeiden ja kirjallisuuden perusteella suositellaan desinfiointilämpötilaksi yli $+15^{\circ} \mathrm{C}$. Jos joudutaan desinfioimaan alle $+10^{\circ} \mathrm{C}$ :n lämpötiloissa, voidaan käyttää $\mathrm{NaOCl}-$, Iobac P- ja Menno-Ter-forte- valmisteita torjuttaessa Botrytis-, Didymella-, Mycocentrospora ja Phoma-sieniä. 